УДК 343.592

DOI https://doi.org/10.32837/pyuv.v0i1(30).540

\author{
О.О.Назарова \\ orcid.org/0000-0002-4979-7562 \\ аспірант кафедри кримінального права, процесу та криміналістики \\ ПВНЗ «Європейський університет»
}

\title{
ДЖЕРЕЛА ВИЗНАЧЕННЯ МОБІНГУ ТА БУЛІНГУ У ВІТЧИЗНЯНІЙ ПРАВОВІЙ НАУЦІ
}

Постановка проблеми. Актуальність теми полягає в тому, що тривалий час про мобінг та булінг не було прийнято говорити взагалі. Вважалося, що таких явищ не існує. І тільки протягом останніх років вітчизняні науковці почали звертати увагу на дослідження зарубіжних авторів про досить важливу та, на жаль, невирішену проблему суспільства - насильство, жорстоке поводження та навіть агресію щодо окремих осіб у навчальних закладах та трудових колективах. Незважаючи на те, що окремі прояви цих явищ є злочинами чи іншими правопорушеннями, сучасна правова наука не містить нормативного визначення понять «мобінгу» та «булінгу». А серед пересічних громадян взагалі мало хто знайомий зі значенням цих термінів.

Стан дослідження. Серед вітчизняних науковців, які досліджують проблематику мобінгу та булінгу, варто виділити С. Бурову, М. Дмитренка, А. Король, О. Лавриненка, Л. Лушпай, В. Панок, В. Синьова та ін. Їхні роботи засновуються на здобутках зарубіжних науковців, які стоять у першоджерел дослідження вказаних явищ.

Метою статті $€$ висвітлення доктринальних джерел для визначення мобінгу та булінгу у вітчизняній юриспруденції для подальшого виокремлення в певних проявах цих явищ ознак правопорушення.

Виклад основного матеріалу. Першими систематичними дослідженнями прояву систематичної та довготривалої агресії серед учнівської молоді займалися скандинавські вчені у 1970 -х рр., і саме вони визначили це явище поняттям «булінг». На початку 1980-х рр. ситуацію повторювальної та систематичної агресії між працівниками на робочих місцях досліджував шведський вчений $\mathrm{X}$. Лейман, котрий визначив це явище через поняття «мобінг». Учені з Великобританії, Австралії та Японії почали співпрацювати з дослідницькою групою Норвегії з метою вивчення явища булінгу в школах, а вчені з Німеччини, Франції, Угорщини, США і Австралії залучилися до співпраці з дослідницькою групою у Швеції з метою дослідження мобінгу на робочих місцях. Оскільки майже одночасно досліджувати прояви систематичної та довготривалої агресії стали дві групи науковців, було прийнято, що поняття «булінг» застосовується щодо шкільних ситуацій, а термін «мобінг» - щодо ситуацій на робочих місцях [1].
Булінг ( «bullying», від анг. «bully» - «хуліган», «забіяка», «задирака», "грубіян», «насильник») визначається як утиск, дискримінація, цькування; цей термін означає тривалий процес свідомого жорстокого ставлення (фізичного, психологічного тощо) з боку дитини або групи щодо іншої дитини або інших дітей [2, с. 44].

Крім того, булінгом можна вважати умисне, що не має характеру самозахисту й не санкціоноване нормативно-правовими актами держави тривале (повторне) фізичне або психологічне насильство з боку індивіда або групи, яка має певні переваги (фізичні, психологічні, адміністративні і т. д.) щодо іншого індивіда, яке відбувається переважно в організованих колективах із певною особистою метою (наприклад, бажання заслужити авторитет в однолітків) [3, с. 8].

Варто зазначити, що А.Б. Орлов трактує різні види насильства так:

- фізичне насильство - навмисне маніпулювання тілом дитини як об'єктом, що призводить до завдання дитині фізичних ушкоджень різного ступеня тяжкості; до фізичного насильства належить не лише побої, а й обмеження дітей в їжі та сні, втягнення дітей у вживання алкоголю та наркотиків тощо;

- психологічне (поведінкове, інтелектуальне, емоційне та ін.) насильство - навмисне маніпулювання дитиною як об'єктом, ігнорування іï суб'єктних характеристик (свободи, гідності, прав тощо), або руйнівні стосунки прихильності, що призводить до різноманітних деформацій і порушень психічного (поведінкового, інтелектуального, емоційного, вольового, комунікативного, особистісного) розвитку;

- сексуальне насильство - навмисне маніпулювання тілом дитини як сексуальним об'єктом, що призводить до залучення дитини в сексуальні дії 3 дорослими з метою отримання останніми сексуального задоволення або будь-якої іншої вигоди; до сексуального насильства належить не тільки сексуальне розбещення дітей, але й залучення дітей у проституцію, порнобізнес тощо [4, с. 183].

Відповідно до зарубіжних досліджень, булінг явище інтернаціональне і досліджується вченими багатьох країн: США, Великої Британії (Канади, Норвегії, Фінляндії та інших). Як зазначає відомий російський науковець I.C. Кон, за останні 
20 років «булінг» став міжнародним соціально-психологічним і педагогічним терміном, який означає складну сукупність соціальних, психологічних і педагогічних проблем [5, с. 15].

Варто погодитися 3 думкою Л. Лушпай із приводу того, що дослідження українських науковців стосовно визначення та характеристики булінгу в основному спираються на зарубіжний досвід [6]. Зокрема, проблему насильства в освітньому середовищі на сучасному етапі розробляють такі українські вчені, як С. Бурова, М. Дмитренко, О. Лавриненко, В. Панок, В. Синьов та ін. Крім того, заслуговують уваги і праці О. Барліт [2], А. Король [7] та ін. Науковий інтерес до явища булінгу з боку педагогів і правознавців не дає змоги комплексно, міждисциплінарно окреслити його сутність, а отже, визначає потребу ретельного аналізу (поряд з окресленими) проявів булінгу також у вимірах психологічної науки, що дасть змогу обгрунтовано підходити до психопрофілактичної роботи та корекції його наслідків в освітньому середовищі.

Відомі британські вчені Д. Лейн та Е. Міллер [8] визначають булінг як довготривалий процес усвідомленого жорстокого поводження, фізичного чи психічного, з боку індивіда або групи щодо іншого індивіда, який не здатен себе захистити в цій ситуації.

Х. Лейманн визначає булінг як «соціальну взаємодію, через яку одна людина (іноді кілька) зазнають нападів іншої (іноді кількох, але, як правило, не більше чотирьох) майже щодня впродовж тривалого періоду (кількох місяців), що викликає в жертви стан безпорадності і виключення з групи» [9].

На думку Л. Кішлі, основною характеристикою булінгу є емоційне приниження, образа почуттів людини, що призводить до виключення її з групи. Дослідниця зазначає, що булінг - агресивна поведінка, яка спрямована на приниження почуттів, висловлювання негативних емоцій і принизливих оцінок щодо іншої людини. При цьому це явище не є порушенням закону, адже в карному кодексі, як правило, немає закону, згідно з яким така поведінка карається. А. Король проаналізовала ознаки булінгу, на які звертала увагу Л. Кішлі. Йдеться про:

1) емоційне приниження, що має вербальні i невербальні способи вираження. Вербальні представлені негативно забарвленими висловлюваннями, використанням підвищеного тону, криком, звинуваченням у помилках, приниженням здобутків і досягнень людини. Невербальні способи - це, насамперед, зневажливий погляд, мовчазне засудження, образливі жести тощо;

2) тривалість емоційно образливої і принизливої поведінки. Жертви булінгу визнають, що навіть, якщо неприйняття і несхвалення висловлюється у порівняно м'якій формі, але впродовж тривалого періоду, виникає відчуття загнаності та відсутності виходу;

3) непривітна і недовірлива поведінка також класифікується як булінг;

4) втручання у приватне життя людини;

5) якщо наслідком агресивного, негативного ставлення до людини є погіршення психологічного і фізичного стану цієї людини, то така поведінка визначається як булінг;

6) якщо агресор має намір завдати шкоду іншій людиніабодозволяє чисприяє, щобця людинапережила травмувальні події, ця поведінка є булінгом;

7) агресор займає вище становище, ніж його жертва і, відповідно, дозволяє собі дії, що принижують гідність і завдають моральної або фізичної шкоди іншій людині [7].

Крім того, булінг не включає кримінальні дії, які починалися як конфлікт та розвинулися, тобто серйозне фізичне насильство, погрози такого насильства, напади. Не кожне здійснюване насильство є булінгом. Суть булінгу вбачають не в самій агресії або злості кривдника, а в презирстві, зневазі - сильному почутті відрази до покірливого, того, хто ніби не заслуговує на повагу. Це дає кривдникам шкодити без почуття провини, співчуття чи емпатії [10, с. 178-179].

Стосовно поняття «мобінг» варто зазначити, що в перекладі 3 англійської мови «to mob» означає «грубити, нападати зграєю, цькувати». Як зазначалося вище, вперше це явище став вивчати на початку 1980-х рр. шведський учений-психолог Х. Лєйман. Під мобінгом у службовому колективі розуміється колективний психологічний терор, цькування щодо кого-небудь із працівників із боку його колег, підлеглих або начальства, здійснювані з метою змусити працівника піти 3 місця роботи або послабити міру його соціального або професійного впливу в колективі [11, с. 332].

Фахівці виокремлюють кілька основних видів мобінгу. Залежно від рівня управління в загальній ієрархії підприємства утиски на робочому місці можуть мати вертикальну або горизонтальну спрямованість. Найбільш поширеним є горизонтальний мобінг, який полягає у психологічному переслідуванні в межах окремого структурного підрозділу серед працівників та характеризується недоброзичливим ставленням до працівника, групи колег або керівників. Причинами виникнення цього мобінгу є заздрість, нудьга, професійні амбіції, занижена самооцінка, низький рівень моральних якостей, асоціальний стиль життя, інші політично-соціальні погляди. Вертикальний мобінг має лінійну спрямованість психологічного терору від керівника, роботодавця щодо підлеглого (босінг). Є три причини цього виду мобінгу. Перша причина - босінг як життєвий стиль - панування, в якому чинником психологічного насильства мобера щодо підлеглих є його аналогічна поведінка 
в повсякденному житті. Друга - компенсація власної закомплексованості керівника, тобто він підвищує власний авторитет за рахунок підлеглих. Третя - некомпетентна управлінська діяльність, що полягає в нездатності організувати здорову робочу атмосферу в колективі керівником, ставити професійні завдання й адекватно оцінювати їх виконання, урегульовувати конфлікти [12, с. 22].

У 1998 р. Міжнародне бюро праці видало книгу «Насильство на роботі» («Violence at Work»), де мобінг прирівнюється до інших видів насильства, у т. ч. вбивства та пограбування. Як різновид мобінгу виділяють також булінг (від англ. bully «задирака, забіяка, хуліган») - вид психологічної агресії, що полягає в приниженні, агресивній поведінці, зловмисному переслідуванні, жорстокості, приниженні честі, гідності та ділової репутації працівника, безпідставному вказуванні на службову невідповідність (некомпетентність) із боку трудового колективу або роботодавця. Зазвичай поняття мобінгу та булінгу вживаються паралельно та ототожнюються, але, на нашу думку, булінг є більш жорстокою формою мобінгу [13, с. 287].

Правове регулювання проблема психологічного насилля на роботі набирає обертів у міжнародному аспекті. 3 позиції Міжнародної організації праці (МОП) психічний терор на робочому місці - це «образливе, мстиве, жорстоке, злостиве або принизливе поводження з окремою особою або групою працівників, що охоплює колективний пресинг або мобінг проти обраного працівника, який стає об'єктом психічного тиску. Мобінг передбачає постійну негативну увагу або критику, ізоляцію особи від суспільних контактів, поширення неправдивої інформації» [14, с. 133].

На міжнародному рівні існує Хартія основних прав Свропейського Союзу, яка визначає недоторканність людської гідності в ст. 1, а ст. 3 гарантує людині право на власну фізичну та психічну цілісність [15]. Також у 1996 р. була прийнята Європейська соціальна хартія (переглянута) (ратифікована Україною), ст. 26 якої передбачає право на гідне ставлення на роботі. Відповідно до цієї статті Україна зобов'язана: поширювати інформацію про сексуальні домагання на робочому місці або у зв'язку з виконанням роботи, сприяти запобіганню таких домагань і вживати всіх відповідних заходів для захисту працівників від такої поведінки, а також поглиблювати поінформованість про систематичні непорядні або явно негативні та образливі дії щодо окремих працівників на робочому місці, або у зв'язку з виконанням роботи, сприяти запобіганню таким діям і вживати всіх відповідних заходів для захисту працівників від такої поведінки [16].

Для України явище мобінгу є досить новим i на законодавчому рівні не визначеним. Зокрема, $€$ інші терміни для його визначення: «психологіч- ний пресинг», «психологічний тиск», «дискримінація щодо співробітника», «утиски на робочому місці». Крім цього, механізм захисту від мобінгу майже не визначений законодавчо. Конституцією України передбачено, що людина, її честь та гідність є найвищою соціальною цінність. Ст. 2 Кодексу законів про працю визначає право на здорові та безпечні умови праці [17]. Законом України «Про засади запобігання та протидії дискримінації в Україні» від 06.09.2012 р. не закріплено поняття «мобінг», але натомість визначаються «утиски», під якими розуміють небажану для особи та/або групи осіб поведінку, метою або наслідком якої є приниження їх людської гідності за певними ознаками, або створення стосовно такої особи чи групи осіб напруженої, ворожої, образливої або зневажливої атмосфери [18]. Аналізуючи це визначення, можна дійти висновку, що воно фактично визначає суть мобінгу як одну з форм дискримінації. Однак загалом закон є значною мірою суто декларативним, оскільки не визначає механізму захисту осіб від мобінгу [19, с. 89-90].

Висновки. Підсумовуючи, варто зазначити, що булінг та мобінг нині існують у вітчизняному суспільстві як об'єктивні, хоча і соціально негативні, явища. Великим недоліком, що заважає ефективно боротися із цими явищами, є відсутність їхнього нормативного закріплення. Ми підтримуємо позицію більшості вітчизняних правознавців, заснованої на результатах вивчення зарубіжних наукових джерел, які пропонують вважати булінгом довготривалий процес усвідомленого жорстокого поводження, фізичного чи психічного, з боку індивіда або групи щодо іншого індивіда в середовищі неповнолітніх осіб, а мобінгом - дискримінацію щодо окремого співробітника в певному трудовому колективі або на робочому місці.

\section{Jimepamypa}

1. Matthiesen S.B., Einarsen S. Perpetrators and Targets of Bullying at Work: Role Stress and Individual Differences society. Violence and Victims. 2007. Vol. 22. № $6 . \mathrm{Pp}$. 735-753

2. Барліт 0.0. Форми і методи подолання (мінімізації) соціально-педагогічної та психологічної проблеми булінгу в освітньому середовищі. Горизонти освіти. 2012. № 2. C. 44-47.

3. Коваль Г.В., Алєксєєнко Г.О. Сучасні підходи до визначення та класифікації булінгу в шкільних підліткових колективах. Наукові праці. Педагогіка. 2016. Випуск 257. Том 269. С. 7-11.

4. Орлов А.Б. Психологическое насилие в семье определение, аспекты, основные направления оказания психо-логической помощи. Психолог в детском $c a \partial y$. 2000. № 2-3. С. 182-187.

5. Кон И.С. Что такое буллинг и как с ним бороться? Семья и школа. 2006. № 11. С. 15-17.

6. Лушпай Л.I. Булінг як соціально-педагогічна проблема та шляхи її вирішення (на прикладі досвіду середніх загальноосвітніх шкіл Великої Британії). Українознавчий альманах. 2010. Вип. 4. С. 126-131. 
7. Король А. Причини та наслідки явища булінгу. Відновне правосуддя в Україні. 2009. № 1-2. 190 с.

8. Лейн Д. Школьная травля (буллинг). Детская и подростковая психотерапия / Под ред. Д. Лейна и Э. Миллера. Санкт-Петербург : Питер, 2001. С. 240-274.

9. Randall P. Bullying in Adulthood: Assessing the Bullies and Their Victims. Florence, KY, USA : BrunnerRoutledge, 2001. URL: http://site.ebrary.com/lib/ bckharkiv/Doc?id=10053591

10. Кормило О. Явище булінгу в освітньому простоpi. Проблели гуланітарних наук. Серія "Психологія». Випуск 35. 2015. С. 174-179.

11. Свдокимов В.О., Конотопцева Ю.В. Шляхи подолання мобінгу в управлінні персоналом державної служби. Актуальні проблеми державного управління. 2012. № 2(42). С. 331-337.

12. Костюк Н., Субченко Д. Перспективи запровадження механізмів правового регулювання мобінгу в Україні. Аспекти публічного управління. 2019. № 9-10. Tом 7. С. 19-31.

13. Чередніченко Н.А. Мобінг і булінг у трудовому процесі. Право і безпека. 2012. № 5. С. 285-288.

14. Лагутіна I.В. Мобінг на робочому місці: правовий аспект. Актуальні проблеми держави і права. 2011. № 37. C. 133-138.

15. Хартія основних прав Європейського Союзу. URL: https://zakon.rada.gov.ua/laws/show/994_524 (дата звернення 31.03.2020).

16. Свропейська соціальна хартія (переглянута). URL: https://zakon.rada.gov.ua/laws/show/994_062 (дата звернення 31.03.2020).

17. Кодекс законів про працю України. URL: https://zakon.rada.gov.ua/laws/show/322-08 (дата звернення 31.03.2020).

18. Закон України «Про засади запобігання та протидії дискримінації в Україні». URL: https://zakon.rada.gov.ua/laws/show/5207-17 (дата звернення 31.03.2020).

19. Федорова Д.О. Проблеми протидії мобінгу в трудових відносинах в Україні та шляхи їх вирішення. Науковий вісник Херсонського державного університету. Серія Юридичні науки. 2015. Випуск 2. Том 2. C. 88-92.

\section{Анотація}

Назарова О. О. Джерела визначення мобінгу та булінгу у вітчизняній правовій науці. - Стаття.

У статті досліджено наявні доктринальні визначення мобінгу та булінгу. Зазначено, що дослідження українських науковців стосовно визначення та характеристики цих явищ в основному спираються на зарубіжний досвід. Булінг охарактеризовано як умисне, що не має характеру самозахисту й не санкціоноване нормативно-правовими актами держави тривале (повторне) фізичне або психологічне насильство з боку індивіда або групи, яка має певні переваги (фізичні, психологічні, адміністративні і т. д.) щодо іншого індивіда, яке відбувається переважно в організованих колективах із певною особистою метою (наприклад, бажання заслужити авторитет в однолітків). Зазначено, що булінг не включає кримінальні дії, які починалися як конфлікт та розвилися, тобто серйозне фізичне насильство, погрози такого насильства, напади.

Під мобінгом у службовому колективі запропоновано розуміти колективний психологічний терор, цькування щодо кого-небудь із працівників із боку його колег, підлеглих або начальства, здійснювані з метою змусити працівника піти з місця роботи або ослабити міру його соціального або професійного впливу в колективі. Залежно від рівня управління в загальній ієрархії підприємства утиски на робочому місці розділено на вертикальні та горизонтальні. Виділено, що найбільш поширеним є горизонтальний мобінг, який полягає в психологічному переслідуванні в межах окремого структурного підрозділу серед працівників та характеризується недоброзичливим ставленням до працівника, групи колег або керівників. Причинами виникнення цього мобінгу є заздрість, нудьга, професійні амбіції, занижена самооцінка, низький рівень моральних якостей, асоціальний стиль життя, інші політично-соціальні погляди. Підкреслено, що вертикальний мобінг має лінійну спрямованість психологічного терору від керівника, роботодавця щодо підлеглого (босінг). Як висновок, зазначено важливість нормативного закріплення аналізованих явищ для підвищення ефективності боротьби з ними.

Ключові слова: мобінг, булінг, насильство, агресія, колектив.

\section{Summary}

Nazarova 0.0 . Sources of mobbing and bulling definition in national juridical science. - Article.

The article examines the existing doctrinal definitions of mobbing and bulling. It is noted that the studies of Ukrainian scientists regarding the definition and characteristics of these phenomena are mainly based on foreign experience. Bullying is characterized as deliberate, not self-protective, and not subject to the statutory acts of the State of prolonged (repeated) physical or psychological abuse by an individual or group that has certain advantages (physical, psychological, administrative, etc.) over another an individual that occurs predominantly in organized groups for a specific personal purpose (for example, the desire to earn the authority of peers). It was noted that bullying does not include criminal activities that started as a conflict and developed, serious physical violence, threats of such violence, attacks.

Mobbing at the service team is intended to understand the collective psychological terror, harassment of any employee by his or her colleagues, subordinates, or superiors, in order to get the employee to leave the workplace or to diminish his or her social or professional influence in the team. Depending on the level of management in the overall hierarchy of the enterprise, workplace harassment is divided into vertical and horizontal. It is emphasized that horizontal mobility is the most widespread, which is psychological persecution within a separate structural unit among employees and characterized by a malicious attitude towards an employee, group of colleagues or managers. The causes of this mobbing are envy, boredom, professional ambition, low self-esteem, low moral standards, asocial lifestyle, other political and social views. It is emphasized that vertical mobbing has a linear orientation of psychological terror from the head, the employer in relation to the subordinate (bossing). As a conclusion, it is pointed out the importance of normative consolidation of the analyzed phenomena in order to increase the effectiveness of combating them. team.

Key words: mobbing, bulling, violence, aggression, 